\title{
Uncovering Wounds, Countering Obliviousness: Tragedy of Humanity in Herztier, a Novel by Herta Müller
}

\author{
Wisma Kurniawati* Setya Yuwana Sudikan Agus Ridwan \\ Program Pascasarjana, Universitas Negeri Surabaya, Jl. Ketintang No.30, Kota Surabaya, \\ Jawa Timur, Indonesia 60231
} The research is financed by Directorate General of Higher Education Ministry of Research an Technology as the
organizer of BPPDN.

\section{Abstract}

Fictional works from Herta Müller are regarded as documentations and information sources of socio-political life in Romania during the dictator Ceausescu regime from 1967 to 1989. Müller's novel Herztier is considered as the most concrete in representing the tragedy of humanity under the practice of totalitarian system power. This study aims to investigate the tragedy of humanity represented in the novel Herztier, and the intentions the author, Herta Müller, wants to achieve through those representations. To understand and achieve profound result, study were performed on Herztier and the social and political contexts relevant to the novel. Therefore, as the theoretical basis, the Stanzel theory of narrative and van Dijk theory of critical discourse analysis are used. By the combination of these theories, the narrative reconstruction, directed at the narrator elements, narrative perspective, narrative intonation, and linguistic choices, also the contexts related to the socio-political facts in Romania during the reign of Ceausescu. The analysis shows two findings. First, the tragedy of humanity shown in Herztier are represented by a first person narrator. Second, through the novel-imaginative fictional stories-, the author tries to provide a means to fight the oblivion about bad events in life and to raise the awareness of the readers about the true reality. The public awareness of reality, in the future, can move them to actively participate in the struggle for a just society.

Keywords: tragedy of humanity, totalitarian system power, narrative situations, critical discourse analysis

DOI: $10.7176 / J L L L / 60-07$

Publication date:September $30^{\text {th }} 2019$

\section{Introduction}

Previous studies shows that Herta Müller's works represent the tragic fate of protagonist characters under proletarian dictator power (Glajar 1997; Haines 1998; Nagy-Szilvester 2013). They are even considered as documentations and information sources of socio-political life in Romania during the dictator Ceausescu regime in power from 1967 to 1989 (Eddy 2000; Ivaşca 2014). Müller's novel Herztier is considered as the most concrete in representing the humanitarian tragedy under the practice of totalitarian system power. Inspired by the author's experience as an activist in her motherland, Romania, the novel shows the struggle of the protagonists against the authoritarian rulers and the consequences they had to suffer. The tragedies experienced by Müller's characters, which are so typical, are often referred to as Müller's world and character.

The results of those studies show that the novel is not only present before the readers as a meaningless fictional work. Herztier is a genre of discourse that is part of the socio-political reality in Romania. In the novel, represented the leadership of the president Ceausescu who applied an authoritarian neostalin style (Alkatiri 2016; Kunze 2016; Pehl 2018). Abuse of power by the authorities resulted in poverty and social inequality, and was further aggravated by the actions of silencing, terrorism, and murder by the police as agents of the authorities. The community survives only if they follow the wishes and commands of the ruler.

Müller's stories are not without controversy. The German author was named a humanitarian warrior because of her persistence in voicing the suffering of Romanian society due to the oppression and abuse of Ceausescu and his cronies. There are not just a few parties that give positive appreciations and awards to her (Haines 1998). As a culmination, she was awarded the Nobel Prize in 2009. However, some others gave negative comments. They assume that Müller is a non-creative author because all of her works only tell about people suffering under totalitarian dictatorial rulers (Wichner 2002), even White (1998) considers that Müller did excessive engineering in her creation stories.

The question is: Should a novel not be excessive? Wellek and Warren (1993) once wrote that a novel could be understood by the readers because of the similarity between the portrayed imaginative world and the reality ("life-like"). In addition, the complexity of the world displayed in novels is one of the factors that makes this genre considered as a work of fiction that is most similar to social life.

In the creative process, the author has "licentia poetica" (aesthetic freedom). Literary works are fictitious and imaginative. Fiction and imagination are individual. By the author, the picture of the world may be beautified or otherwise aggravated. She stated, if a person experiences one and the same event over and over again, then she can create similar imaginative events. As a defense, Müller stated that her novels - including 
Herztier - were indeed motivated by her autobiography, but they were imaginative creations, and called her works of fiction to be autofictional (Haines and Littler 1998).

This research is intended to investigate the tragedy of humanity represented by Müller in Herztier, and the intentions the author wants to achieve through those representations. To understand and achieve profound result, study were conducted on Herztier and the social and political contexts relevant to the novel. Therefore, as the theoretical basis, the Stanzel theory of narrative and van Dijk theory of critical discourse analysis are used. In novels, narrative situations are the most important element because they can determine the meaning and objectivity of stories (Stanzel 1995). The narrative situation, on the one hand can show the aesthetics of a novel, but on the other hand it is also seen as a work that is related to social and cultural situations.

The narrative situation includes story elements and the narrator. The story is the object that is discussed in, while the narrator is the party who tells about the fictional world. The story is the basic material of the novel that is imitated from the reality of life, but the narrator determines the model of the world displayed. The narrator is the party who tells the story as a whole, and controls reading comprehension and attitude. When telling a story, the narrator is in a certain position. The position raises two aspects, namely the narrative "point of view" (perspective) and tone of narrative. The narrative perspective refers to the starting point that shows the position of the narrator when looking at the world, whether she is in a space with a character or is outside the space occupied by a character. The tone of narration shows the narrator's attitude and views. The narrative perspective on the world of stories and the tone of narrative has a profound effect on the meaning given to the world of story. As a party that assesses, feels, and views, the narrator becomes the determinant of the objectivity of the meaning of the text. How the fictional world must be viewed, and with whom the world must be seen, is directed by the narrator.

From the point of view of critical discourse theory, novels are considered as one of written discourse genres (van Dijk 2011). Novels are part of the representation of certain societies. The novel constructed by the author is related to the reality that she understands. Medium of novel is language. On the one hand, language shows values that are spread in society because language is formed socially and the meaning of language is based on social agreement. On the other hand, language is also influenced by the political power of the ruler. Therefore, novels are considered to represent social political reality. However, the use of language also shows the author's knowledge, attitude and ideology. Behind the production of a discourse, there is always a specific purpose.

Van Dijk (2011) believes there are three dimensions in discourse, namely the dimensions of text, social cognition, and social reality. These three dimensions are a means of analysis to understand discourse. The text dimension refers to the structure of the text, the dimension of social cognition refers to the cognition of the author as an important aspect in the production of text, and social reality refers to the discourse that develops in society.

Based on Stanzel and van Dijk's theory above, this study is intended to describe the image of the tragedy of humanity in Herztier displayed through first person narrator. This research is considered relevant because of the novel, although it is an imaginative fictional story, but it can be a means to resist the obliviousness of bad events in life and giving readers awareness about the reality of life. As stated by Miles (2016) about the function of the novel, namely "Erzählen - Gestalten" ("telling - building" / telling stories - forming or building). The story can function as "Bildung" (education) because it can foster public awareness of reality (Lukács 1952). That awareness, in the next stage will move them to actively participate in the struggle to create a just society.

\section{Method}

\subsection{Methodological Approach}

To describe the objective picture of humanity tragedy in Herztier, a qualitative approach is used because data sources are natural, and the study is intended to find the meaning of the novel. In the process of understanding, combination of Stanzel's narrative theory and van Dijk's critical discourse theory are used as the theoretical basis. Through the combination of the two theories, the analysis of the novel is carried out on the narrator's elements, narrative perspective, narrative tone, and linguistic elements that reflect the three dimensions of discourse, namely the dimensions of text, social cognition, and social reality. The text dimension refers to the structure of the text, the dimension of social cognition refers to the cognition of the author as an important aspect of text production, and social reality refers to the discourse that develops in society, which is related to socio-political reality in Romania during the reign of president Ceausescu.

The researcher acts as an instrument. Since data collection until its presentation, the researcher is involved intensely in the process of understanding and interpreting data. The source of primary data in this study is the novel Herztier in German version, published in 2015 in Frankfurt am Main by Fischer Taschenbuch.

\subsection{Procedure of Data Collection and Analysis}

The process of data collecting and analyzing in this study was carried out by the method of critical discourse analysis of the van Dijk model. To understand the representation of the humanity tragedy in Herztier and the 
author's intention, the study is carried out by the following steps (1) marking the elements of narrative in Herztier, including the narrator, the point of view, the tone, and the linguistic elements which has social power; (2) listing the elements from number (1) and make a coding. Codification system example: (HT,60 : p.81) $\rightarrow$ HT $=$ novel Herztier, 60 = part of the novel, p.81 = page of the quoted part; (3) interpreting the novel's macro structure that can be observed, such as global topics / themes expressed through titles and thematic sentences, sentences which has activated semiotic elements; (4) interpreting the structure / framework of the novel which is expressed in the local elements that are deliberately chosen by the author, namely words, structure of propositions, coherence, and relationships between propositions, and forms with implicit and indirect meanings, such as implications, presuppositions, allusion or elements that are not controlled by the author, for example intonation, syntactic structure, structure of propositions, rhetorical language, or forms commonly used in spontaneous conversations, such as pauses, speech shifts, improvements, doubts, and pragmatic forms that there are communication events, for example intentions, speaker emotions, participants' perspectives on communication of the topic being discussed, opinions of the other person; (5) The choice of local elements analyzed is always based on the relevant context, namely the local context that is related to the characteristics of the interaction situation, for example the organizational structure, gender, race, and global context that also determines communicative events, namely social structures, politics, culture, or history; (6) interpreting mental models (schematic representations of relevant personal and social events, such as background, participant roles in communication or actions).

\section{Analysis and Discussions}

\subsection{Representations of Humanitarian Tragedy in Herztier}

The humanitarian tragedy in Herztier is represented in the title, thematic sentences, and choice of linguistic elements. The advantages of first person narrative, which at the same time acts as the main actor, "Ich" (I) is that it able to report events that are experienced by themselves or report incidents related to other characters who establish personal contact with the main character. Apart from the advantages, the first person narrator also has disadvantages. She cannot report on the events or activities of characters who are not accessible to his vision and hearing. Therefore, the integrity of the story is obtained from the use of turn-taking techniques. The primary narrator "Ich" bestows on the task of secondary narrators - Edgar, Georg, Kurt, Pjele, Lola, Tereza - to report on the events they experienced, saw, and heard. Like the primary narrator, secondary narrators also report their thoughts, feelings, and attitudes. Through the turn-taking technique between the primary narrator and secondary narrators, the story becomes whole.

The first representation of humanitarian tragedy portrayed in Herztier appears in the title. The word "herztier" (animal heart) is a combination of two words, "herz" (heart) and "tier" (animal). The word is not a commonly used word so it is not easy to interpret it just by looking at or reading the title. However, the word is used in part 59 and 60, as a form of chemistry which means bad or evil.

Die singende Großmutter ist die Dunkle. Sie weiß, daß jeder ein Herztier hat. Sie nimmt einer anderen

Frau den Mann weg. Aber sie bekommt ihn, weil sie ihn haben will. Nicht ihn, sondern sein Feld. (The grandmother who likes singing is an evil / bad grandmother. She ["Ich"] knows that everyone has animal heart. She [the grandmother who likes singing] takes people's husbands. She gets him because she wanted to take his field) (HT,60:p.81).

This quote indicates the word herztier is interpreted as a bad side or a evil side of human. It is believed that everyone has a bad side like the grandmother of "Ich". However, the explanation is not complete. The full meaning can only be obtained after the reader completed the Herztier story through thematic sentences in each part of the novel and other local elements.

The humanitarian tragedy represented in Herztier is further elaborated in thematic sentences and in the fabric of the story. As a narrative text, the main characteristic of the novel is the primary narrator "Ich" and the secondary narrators. The use of turn-taking techniques of primary and secondary narrators, the narrative perspective and the tone of narrative used in the novel forms a whole topic. "Ich" as the primary narrator is the party who reports the story from the beginning to the end. In addition, she also acts as the main actor in the fictional world.

Through the narrator "Ich" report, it is shown the social political situation and conditions in Romania. The story world is inhabited by people who are divided into two major groups, the ruling group and community groups. The ruling group is represented by "der Dictator" (the dictator), "Wächter" (guard) and "Securitate"/"Polizei" (intelligence/police), while community groups are divided into smaller groups, namely intellectual groups, factory workers (proletariat), and other civil society. The existence of these two groups, among others, can be seen from Edgar and "Ich" conversations, which are still overshadowed by murder eventhough they are already outside Romania.

Und wenn ich mir das denke, dann ist mir, als ob jeder Tote einen Sack mit Wörtern hinter sich läßt. (If I think about it [death], every death leaves a sack of puzzles). 
Sie spüren vielleicht anders als wir, daß der Diktator ein Fehler ist, sagte Edgar. (They may not realize as we do, that a dictator is a mistake, Edgar said) (HT,1:P.7).

In Edgar's words, "Sie" refers to the apparatus who supports the dictator, namely the "Securitate" (intelligence), "Wächter" (guard), and other supporters, while the "wir" can refer to Edgar, "Ich", and the group, but it can also implicitly involves the reader. The author contrasts two parties, namely "wir" (us) and Dictator and "sie" [dictator and apparatus who side with him].

The dictatorial ruler in the story of Herztier has authoritarian power that is unlimited and untouched. The public can only read his speeches once a week in the paper.

Seit Monaten wechselte Lola einmal in der Woche die Wandzeitung im Glaskasten des Studentenheims.

Dann wechselte sie die Zeitungsausschnitte, zerknäulte die vorletzte Rede des Diktators und klebte die

letzte Rede hinein. (For several months now, Lola has changed the wall newspaper in the glass box of the dormitory for once a week. She wringed the pieces of the newspaper containing old speeches, and replaced them with the latest ones) (HT,9:p.20).

However, the choice of word "zerknäulte" (wringing) in the statement above could have a pejorative meaning. A form of activity that can be seen as degrading/disapproving the dictator.

All means are intended to spread the ruling ideology as well as a tool to perpetuate his power. With a metaphorical and personification style, a speaker, that usually only functions as a tool to amplify the sound when people speak or the sound from a cassette or CD to be heard in a wider radius, is also portrayed having the ability of seeing and hearing everything.

... an der Decke über der Tür ein Lautsprecher [gebaut]. Die Arbeiterchöre sangen von der Decke zur Wand, von der Wand auf die Betten, bis die Nacht kam. Jemand sagte, die Lautsprecher sehen und hören alles, was wir tun. (Above the door, a speaker is installed. Proletarian Mars is heard from the roof to the walls, from walls to beds, until midnight. People say that the speakers can see and hear everything we do)

(HT,5:p.11).

However, his enormous power covers all the joints of life in Romania. An authoritarian dictatorial system seems very clearly affecting people's lives. Through the state police, the guards, their power does not only regulate the system of government, state institutions, and affairs that concern the lives of the people at large, but also arrive at personal matters. In everyday life, people do not have freedom. All their movements are monitored. Supervision was carried out by the police, by guards scattered in all directions. All housing built by the government is installed by tapping equipment, which oversees all movements of the community. Tapes are not only installed in public areas, but also in private rooms.

To maintain power, any form of community activity that is deemed capable of destabilizing or endangering the authorities, is thrown into prison, killed or deported abroad. Not a few people who try to go abroad secretly, must die at the border. Bodies lying at the border and in empty fields are everyday sights.

Government policies in the economic field have created a gap in society. Wealth is only owned by the ruler and his cronies, while others experience poverty. "Jede Gegend im Land war arm geblieben" (all regions in that country [Romania] are poor) (HT, 2: p.9). The farmers were sent to the city to become factory workers. Farmland is not taken care of, resulting in drought. In the city factory workers occupy plain apartments built by the government. They get inadequate salaries so they commit various crimes, such as stealing. Factory supervisors become corrupt people. They are easily bribed.

The intellectual group is represented by the protagonists - Edgar, Georg, Kurt, and Ich. In all the limitations they faced, the four friends carried out various activities to express their protest and resistance to the authorities. They conducted an investigation secretly when Lola - a student who lived in a room with "Ich" in a student dormitory - was found hanged in a wardrobe.

Und Lola hing an meinem Gürtel im Schrank. (And Lola hanged herself with my belt ["Ich"'s belt] in the wardrobe (HT,16:p.30).

Im Glaskasten hing Lolas Bild,.... Unter dem Bild hing ein Blatt: Diese Studentin hat Sebstmord begangen. Wir verabscheuen ihre Tat und verachten sie. Es ist eine Schande für das ganze Land. (On the wall there was a picture of Lola, .... Below the photo was a paper with the words: This student committed suicide. We condemned her actions. That act became a disgrace to the country) (HT,17:p.30).

They believe that Lola did not commit suicide, as officially reported by the police, parties, and universities. Their suspicion of Lola's death which seems unnatural, is getting stronger, when "Ich" reads Lola's diary, which was tucked into her suitcase. Through Lola's notebook, it is known that Lola went to the city because of her poverty. To get potential husband who can improve their social and economic status, Lola majored in Russian. She is sure to be accepted as a student because the department does not have many registrants. During college, every night Lola's activities only looked for the man she wanted. In the last year of his lecture, she was appointed as a party member and related to sports lecturers. The catastrophe happened because Lola, who was impregnated by a sports lecturer, demanded responsibility for her pregnancy.

While investigating the causes of Lola's death, "Ich" together with three of her friends - Edgar, Georg, and 
Kurt - carried out various activities which were prohibited or covered up by the ruling elite. They routinely read smuggled books from abroad, which are prohibited by the authorities. They also created critical poems. Because of these activities, "Ich" and her three friends were always observed by the secret police. All their gestures are always watched. They were also summoned by police for interrogation, and threatened with death.

After graduating from university, the four friends remained targeted by the police. They are employed in far-flung cities. Their gestures are still being watched. Even though they have lived in different cities they still meet regularly. They also always communicate by mail. However, their activities were immediately discovered by the intelligence. "Ich" and Edgar were deported to Germany, but they were still monitored. "Ich" was spied by his own friend, Tereza.

Ich war nicht im Land. Ich war in Deutschland und bekam die Morddrohungen vom Hauptmann Pjele aus der Ferne als Anrufe und Briefe. (I was not in the country [Romania]. I was in Germany and received the death threats from Captain Pjele from a distance by calls and letters.) (HT,115:p.157).

Moments later, Georg was also deported to Germany, but a few days later she was found dead in his room. Kurt, who was still in Romania, was soon found dead hanging himself in a tree.

The enormous pressure of the authorities on the community triggered resistance carried out by the community individually and clandestinely. The ruling group is antagonistically opposed to the intellectual group, while the proletariat and civil society groups are described as groups that are unconsciously living in a system built by the ruling group. The resistance of the proletariat and civil society, by pretending not to know, gossiping, or stealing, is known as the Brechtian style resistance.

\subsection{Representations of Humanitarian Tragedy in Herztier as a means of Countering Obliviousness and as a Form of Awareness}

Herztier was Müller's first novel after she was deported from Romania. This novel was published in Germany the first time in 1992. Since 1987 she has settled in Germany (then West Germany). Even though she was not in his home country, Müller was still threatened by telephone and spied on. One of the spies was her best friend in Romania.

Along with the wave of reformation that took place in Eastern Europe in the late 1980s, the communist regime led by president Ceausescu collapsed. However, different from the neighboring countries such as Hungary, Czechoslovakia, Albania which experienced a change in the system of government in a peaceful manner, in Romania there were bloody reformation because Ceausescu was not willing to resign voluntarily. He and his wife were eventually killed by a group of armed forces who defended the people (Alkatiri 2016).

The tragic events experienced by Müller and the people around him became an inspiration in creating the Herztier novel. The humanitarian tragedy represented is a manifestation of the author's resistance to authoritarian dictatorial rulers. The resistance is described explicitly or implicitly. Explicit resistance is represented through protagonists - "Ich", Edgar, Kurt, and Georg as manifestations of disagreement and opposition to the authorities. Implicitly the resistance is illustrated by being shown through a picture of social political irregularities due to political policies, and also silencing and oppression by the authorities.

Implicit resistance is also raised through rhetorical strategies. From the storytelling strategy, the Herztier story is presented as a flashback story. Through the dialogue "Ich" and Edgar in the first part of the Herztier story, the reader is invited to introspect, related to the guilty party. The author contrasts two parties, namely "wir" (we) antagonistically in conflict with the dictator and "sie" [dictator and apparatus on his side]. Through ways and forms of storytelling that are diverse and not patronizing, Müller's story seems to flow spontaneously, as if a form of story is told verbally. The strategy is able to bring the reader into the story and identify themselves together with the protagonists created by the author, so that readers can share in the suffering of the characters facing various problems presented.

The conversation conducted by "Ich" with Edgar, his best friend, is a motive that reflects the whole story. Through the conversation between "Ich" and Edgar, the reader cannot understand, when only reading the first part of the story. The conversation seemed to be put in place by the author at the beginning to provoke readers' curiosity. Like a puzzle, the part is answered little by little, sheet by sheet. And the final part is a short answer to the puzzle at the beginning, as well as conclusions from the whole story.

Herztier is divided into 216 parts. The parts are not given a title. Beside the separation of part one into part two (which is different than other parts separation), the beginning of new part is not placed on a new page. Separation between sections is characterized by the use of bold letters with a larger size, when compared to other letters. The new section is placed on the same page as the previous section, but is marked with a wider space size.

"Ich" realizes that she and Edgar are still spied on. Murders still overshadow their existence. Based on testimonies and news about the death of his close friends, she could not guess, about how she would be killed, whether hanged with a belt like Lola, his roommate, or dropped from a window like Georg, or hung with rope like Kurt.

However, his optimism remained high because expectations continued to grow in those who realized the 
meaning of "die Freiheit des Kopfes und die Freiheit der Füße" (essential human freedom - freedom of thought and act) (Müller 2009). Optimism is symbolized by "Gras" (grass).

Das Gras steht im Kopf. Wenn wir reden, wird es gemäht. Aber auch, wenn wir schweigen. Und das

zweite, dritte wächst nach, wie es will. Und dennoch haben wir Glück. (Grass grows on the head. Whether

we talk or are silent, the grass is cut down. However, the second grass, the third, grows steadily, according to their wishes. Therefore we must be happy.) (HT,8:p.8).

The suffering that caused life's bitterness in the Herztier novel was a humanitarian tragedy that should not be forgotten. Through the optimism displayed in this novel, the author tries to provide a means to resist the obliviousness of bad events in life and to raise the reader's awareness of the reality. Public awareness of reality, at a later stage, can move them to actively participate in the struggle of creating a just society.

\section{Conclusion}

Based on the analysis of text and context, this study produced two findings. First, the tragedy of humanity in Herztier is represented by the first person narrator. Second, through novels - imaginative fictional stories -, the author seeks to provide a means to resist the obliviousness of bad events in life and to arouse the reader's awareness of the real reality. Public awareness of reality, at a later stage, can move them to actively participate in the struggle of creating a just society.

\section{References}

Alkatiri, Z. (2016). Transisi Demokrasi di Eropa Timur: Baltik, Jerman Timur, Rumania \& Balkan. Jakarta: Yayasan Pustaka Obor Indonesia, p. 111-121.

Eddy, B.D. (2000). Testimony and Trauma in Herta Müller's Herztier. German Life and Letters, Oxford \& malden: Blackwell publishers Ltd. 53, 56-72.

Glajar, V. (1997). Banat-Swabian, Romanian, and German: Conflicting Identities in Herta Müller's Herztier. Monatshefte, 89, No. 4, 521-540.

Haines, B. and Littler, M. (1998). Gespräch mit Herta Müller. Contemporary German Writer: Herta Müller, Cardiff: University of Wales Press. 14.

Haines, B. (1998). Herta Müller: Outline Biography. Cardiff: University of Wales Press, 11-13.

Ivaşca, R. (2014). Herta Müller: History told through Ekphrasis. History-archaeology Series, Annals of the University din Oradea, Tome XXIV, 153-163.

Kunze, T. (2016). Nicolae und Elena Ceausescu (1989). [Online] Available: https://www.lexikon-derpolitischen-strafprozesse.de/glossar/ceausescu-nicolae-elena-ceausescu/

Lukács, G. (1952). Balzac und der französische Realismus, Berlin: Aufbau-Verlag.

Miles, D. H. (2016). Reality and the two Realisms: Mimesis in Auerbach, Lukács and Handke. Monatshefte, 372-375, http://www.jstor.org/stable/30165459.

Müller, H. (2009). Heimat ist das was gesprochen wird. Merzig: Gollenstein Verlag, 12-13.

Müller, H. (2015). Herztier. Frankfurt am Main: Fischer Taschenbuch Verlag.

Nagy-Szilvester, O. (2013). Protest and Literature - Herta Müller 's Der Fuchs war Damals schon der Jaeger and Herztier. Studies on Literature, Discourse and Multicultural Dialogue, Târgu Maureş: Archipelag XXI, 1183-1192.

Pehl, G. (2018). Behutsame Reformen in Rumänien. [Online] Available: http://library.fes.de/gmh/main/jahresin/1968/jahres_10-1968.htm

Stanzel, F. K. (1995). Theorie des Erzählens. Gottingen: Vandenhoeck \& Ruprecht.

van Dijk, T. (2006), "Discourse, Context and Cognition," Discourse Studies, London, Thousand Oaks, CA and New Delhi: Sage Publication, vol. 8(1), 159-177.

van Dijk, T. (2011). Discourse Studies and Hermeneutics. Discourse Studies, 1-13.

van Dijk, T. (2011). Multidisciplinary CDA: a plea for diversity. Methods of critical Discourse Analysis, London, California, New Delhi: Sage Publication, 95-120.

Wellek, R. and Warren, A. (1993). Teori Kesusastraan. Jakarta: Penerbit PT Gramedia.

White, J. J. (1998). Die Einzelheiten und das Ganze: Herta Müller and the Totalitarianism. Contemporary German Writer: Herta Müller, Cardiff: University of Wales Press.

Wichner, E. (2002). Herta Müllers Selbstverständnis. Text und Kritik: Zeitschrift für Literatur, vol. VII, 3-5. 